\title{
Social Capital and Climate A First Statistical Approach
}

\author{
Marta Felis-Rota ${ }^{a}$ \\ Dept. Análisis Económico: Teoría e Historia Económica \\ Universidad Autónoma de Madrid
}

\begin{abstract}
Social capital has been proved to be related to economic growth, financial development and economic performance in general. The purpose of the present article is suggesting a link between social capital and climate. The paper serves as a first statistical test on whether climatic differences between countries are linked social capital differences. Climate is taken as given and then systematic differences in what different climates of the world could have had on the social capital index have been tested. The relationship between climate and social capital remains significant after controlling for income, education and life expectancy. The results show that temperate climate is favourably associated to high levels of the social capital index; while tropical, dry climate, and climate of high heights are inversely related. Moreover, dry climate and climate of high heights (both extreme climates) seem to have a similar effect on social capital, as we cannot appreciate a statistically significant difference between them.
\end{abstract}

Keywords: Social capital, climate, economic growth

JEL Classification: O13, Q5, Z13

a I would like to thank Antonio Ciccone and Joachim Voth from Universitat Pompeu Fabra; and Jose L. Zofío and Inmaculada Alvarez from Universidad Autónoma de Madrid for their useful comments on this paper. I would also like to acknowledge financial support from Universitat Pompeu Fabra during my period of first investigation on this topic. Opinions reflect solely those of the author. E-mail: marta.felis@uam.es

Recibido: junio de 2010. Aceptado: septiembre de 2010 


\section{RESUMEN}

El capital social se ha relacionado con el crecimiento económico, el desarrollo financiero y en general con la evolución de la economía. Este artículo apunta a un posible vínculo entre capital social y clima. Se presenta un primer análisis estadístico sobre diferencias climáticas y sus correspondencias con diferentes niveles de capital social para un amplio espectro de países. Los resultados muestran que la relación entre clima y capital social sigue siendo significativa una vez controlados los datos por niveles de renta, educación y esperanza de vida. El clima templado se asocia positivamente a altos niveles de capital social; mientras que los climas tropical, seco y de altura son inversamente proporcionales al índice de capital social. De los resultados se desprende, además, que los climas seco y de altura (climas extremos) parecen tener similitud en su efecto sobre el capital social, pues no se pueden distinguir diferencias estadísticas significativas entre ellos.

Palabras clave: Capital social, clima, crecimiento económico

Clasificación JEL: O13, Q5, Z13

\section{INTRODUCTION}

In order to improve the understanding of the functioning of an economy we need to know where social capital comes from. This paper is a contribution towards the better understanding of what explains social capital differences across countries. The aim of this paper is not so much deepening into measurement issues or its consequences, but presenting and testing a hypothesis of how differences in levels of social capital could be originated by truly exogenous determinants.

What is the relationship between social capital and climate arising from? Agder (2003) argued that social capital is an important factor in order to be able to deal with risk situations associated to climate variability in Southeast Asia and the Caribbean. He claimed that social capital matters for resource management since it facilitates networking and communal association. In this sense, his work could be associated to Sen (1981), where he claims that it is entitlements to resources that matters, more than availability. Agder (2003) presents several case studies in which risk associated to climatic variability is translated into increased bonds in the community. In this way, he presents a theoretical link between social capital and increased risk associated to climate change. The purpose of the present article is not dealing with the evolution of climate and the consequences of climate change, but analysing the climate effects taking climate as 
given and then analysing differences in what different climates of the world could have originated. The focus lies on testing whether climatic differences between countries have some effect into social capital differences.

Section II defines social capital; section III details the theoretical basis; section IV goes into the empirics, both explaining the methodology and giving some interesting results; and, finally, section $\mathrm{V}$ presents the conclusions.

\section{Social CAPITAL}

At this point, after two decades of literature on social capital, it does not need any further definition any more. Nevertheless, it is useful reminding that the value of a well functioning society and trustful interactions among its agents has been recognised as a relevant factor in the performance of the economies. The most accepted definition of social capital is that of Putnam (1993). According to him, social capital 'refers to features of social organisation, such as trust, norms, and networks, that can improve the efficiency of society by facilitating co-ordinated actions' (Putnam, 1993). Woolcock (1998) adds that there are four dimensions of social capital: the size and scope of horizontal associations; social integration, the nature of social ties within communities; the relationship between civil society and the state; and, the quality of institutions. As a way of summarising the various proposed definitions, social capital can be understood as the social links amongst citizens, such as trust, norms, and networks. In the abstract, it can be interpreted as the quality of civil society.

Further study of the concept of social capital is needed. In order to measure social capital, researchers should previously devote some efforts to wonder about the mechanisms originating it. It is pragmatically impossible to directly measure an abstract concept, and, therefore, quantification has to be done through proxies, derived from previous theoretical reasoning. Therefore, researchers should be able to understand what causes social capital before jumping into other considerations.

\section{THEORY}

Among all the schools of thought trying to explain development and economic growth, two big streams might present some interesting interactions: These are, on the one hand those studies relating social capital to economic growth, particularly depar- 
ting from Abramovitz (1986)'s social capability, and, on the other hand, those relating geography to economics.

\subsection{Social Capital and Economic Growth}

As far as the linkage between economic growth and social capability is concerned, the first related quantitative study was undertaken in the 1960 's by Adelman and Morris $(1965,1967)$. Obviously, they never used the term 'social capital' since this was coined in the 1990's, but their reasoning is clearly pioneering this branch of thought. The underlying idea is that some societies are more suitable than others as far as economic development is concerned, or at least have different patterns of achieving economic development. Societies have a series of features that defines them and that could affect entrepreneurship and other economic conditionings, such as family relations, the extent of communications, the importance of the middle class, and social mobility. Adelman and Morris used a series of socio-economic variables in a cross-country investigation looking for differentiated patterns of development in developing countries, ranging form the structure of land ownership to political representativeness. Temple and Johnson (1998) used this index to explain subsequent economic growth with successful results. Other papers such as Easterly and Levine (1997) looked for macroeconomic consequences of social arrangements. They indicate that some poor policy outcomes are originated by the nature of societies. La Porta et al. (1997) find some effect of social capital on economic growth for the period 1970-93; Knack and Keefer (1997) study the period 1980-92, and find a stronger link: If the level of trust increases by 10 percent, growth is, on average, 0.8 percent higher per year. This is a very considerable effect. Therefore, it stands clear from the existing research that social capital has some economic consequences, and it makes the difference as far as economic growth is concerned.

So, economic growth literature has acknowledged the effects of social capital, but it has not still been fully incorporated into growth models. Chou (2006) accounts for the three different ways social capital has been thought to be incorporated in growth modelling. First, boosting the accumulation of human capital (à la Coleman) - see Dinda (2008) for a unisectoral growth model -; second, helping financial development (see Guiso, Sapienza, and Zingales, 2004); and, finally creating networks of information within and between firms that would improve efficiency and potentially increase innovation. At this respect, Zak and Knack (2001) present a general equilibrium model where agents have to make the decision of either trusting other agents or investing in verifying other agents' actions. 
Now, it is important to understand what influences social capital and, hence, much more investigation needs to be done into the causes that give rise to different levels of social capital. As we have seen, a substantial amount of work has been done about its effects, but very little into its exogenous causes. So, the underlying question is: What can be differences in social capital be attributed to? Notice that we are not going to discuss endogenous determinants, as could be the level of income per capita, or education (see Coleman, 1988, or Fukuyama, 1995). These could be explored in a posterior stage through modelisation. Still, the direction of causality could be very hard to determine. A task to be performed first is enquiring about the truly exogenous factors, which must be the ones acting first in the causality chain. The hypothesis tested in this paper is whether a truly exogenous geographical factor, climate, can influence economic performance through social capital.

\subsection{Geography and Economic Growth}

A diversity of studies in Economics has empirically demonstrated that Geography matters for economic performance in several ways. Direct correlation between Geography and economic growth has been detected by cross-country growth regressions. Researchers have frequently been unable to eliminate a geographical dummy variable; a large part of the slow growth is left unexplained by the usual set of variables. As an example, studies such as Barro (1991 and 1997), Schimdt-Hebbel (1996), Sachs and Warner (1997), and Easterly and Levine (1997) consistently find that the African dummy is significant and negative. Using a different geographic indicator, Hall and Jones (1999) document the correlation between the distance from the equator and economic performance. Redding and Venables consider natural resource endowments, physical geography variables; as well as institutional, social, and political characteristics as 'exogenous determinants of technology' (Redding and Venables, 2004). Once the link between Geography and economic growth has been proved, some work has already been done on enquiring about the mechanisms that link the two.

Gallup and Sachs (1999) draw the emphasis on the importance of geographical features on the communications network and the policy choices. 'We find that location and climate have large effects on income levels and income growth, through their effects on transportation costs, disease burdens, and agricultural productivity, among other channels. Furthermore, geography seems to be a factor in the choice of economic policy itself'. According to Gallup and Sachs (1999), adverse geographical factors would lead to protectionist policies, linked to high levels of taxation. 
Another strand of the literature has argumented that Geography matters through institutions. This flow of thought is epitomised by the economic historians Engerman and Sokoloff (1997), who find differentiated paths of development in the New World colonies, depending on what they call 'factor endowments'. Some further research argued that Geography matters only through institutions, of which Acemoglu, Johnson, and Robinson (2001); Easterly and Levine (2003); and Rodrik, Subramamian, and Trebbis (2004) are representatives. They instrument institutions with geographical variables and show that it is through geography that institutions matter.

Sachs (2003) shows that including the risk of malaria as one of the geographic controls results in strong rejection of the Acemoglu, Johnson and Robinson (2001)'s hypothesis. Is it a fact that malaria is intrinsically a disease of warm environments, characteristic of the tropics and sub-tropics. The relevance of the malaria as a direct economic indicator has previously been underlined by Gallup, Sachs, and Mellinger (1999), and Gallup and Sachs (1999). Acemoglu, Johnson, and Robinson (2001) argue that the disease environment could have affected the decisions of the settlers regarding the institutional set-up in the colonies, agreeing on the relevance of the disease environment. They build a theory according to which colonisers finding inconvenient climate and disease environment do not settle and institute extractive institutions only. But, as Sachs (2003) shows, the relevance of malaria incidence suggests to be capturing something else, apart from its potential influence on the colonial settlers' decisions. If we think that malaria is a tropical disease, one should become interested in investigating new channels of climate implications.

\section{EMPIRICAL StRATEgY}

There seems to be some future exploring the potential relationship between geography and social capital. The following empirical approach explores the social development index of Temple and Johnson (1998), inspired by Adelman and Morris and checks whether a statistically significant correspondence with climate exists. Indeed, if we take the social development index for the moment being as an initial proxy for social capital, we find a surprising geographical match between low and high scored countries. This suggests that the origin of the social capital in a given country might be related to geographic circumstances.

In order to test this hypothesis, I construct a pooled database, together with the standard variables included in the growth regressions, and then proceed to explore the statistical evidence of this relationship. My approach is focused on the geographical 
characteristics overall. In the first empirical approach that follows, I select climate as the variable summarising several geographic characteristics. Indeed, climate will vary with latitude, height, rainfall pattern, number of sunny hours, and proximity to the coastline. I then proceed to test whether it has some influence on social capital or not.

\subsection{Methodology and Data}

The scientific focus is mainly positivistic; i.e., the criteria to obtain reliable knowledge are based on the possibility to test, observe, and control. We have gathered a database in order to test the theory of climate as the origin of social capital. The aim of this section is to clarify the sources of the collected data and the perspective from which data have been processed and analysed. The first step to contrast my proposal is by constructing a correlation matrix between the social development index and the variables acting as climatic indicators. Then, we have performed tests by means of ordinary least squares regressions and tests for coefficient's restrictions. Then, multivariate regression analysis will include the variables of control in order to bring robustness to the results.

The data come from various sources. The list of countries and the macroeconomic variables are as they appear in the Penn World Tables constructed by Heston and Summers. These tables offer macroeconomic information about 125 countries. The series referring to education are the ones used by Lee and Barro (2001). Life expectancy comes from the statistics of the National Bureau of Economic Research. The social development index created by Adelman and Morris (1967) has been incorporated to the database. We use this index since it is the most comprehensive; i. e. it encompasses a wide range of socio-economic indicators. The series taken are those appearing in Temple and Johnson (1998), who successfully reproduce this index for 42 less developed countries. Finally, the climatic information comes from the statistics of the World Factbook. Following this information, new series of climatic dummy variables are constructed. This is, there is a variable for each type of climate, filled with ones and zeros depending on whether every country is predominantly falling under the indicated type of climate or not. The climatic typologies are the following:

1. tropical climate;

2. dry climate;

3. temperate climate;

4. cold climate; and

5. climate of high heights. 
When several climatic zones are present in one country, the observation has been classified under the climatic characteristics corresponding to the largest part of the territory. All countries have been grouped into one of five climatic typologies, except China, which appeared to be too diverse to classify.

\subsection{Results}

The first result comes from the calculation of the correlation matrix between our social capital proxy (the social development index of Adelman and Morris) and each of the climatic dummies.

The correlation matrix is as follows:

TABLE 1. Correlation Matrix between the Social Development Index and Climate

\begin{tabular}{|l|c|c|c|c|c|}
\hline & SOCDEV & TROPICAL & DRY & TEMPERATE & HEIGHTS \\
\hline SOCDEV & 1.0000 & & & & \\
\hline TROPICAL & -0.1605 & 1.0000 & & & \\
\hline DRY & -0.2067 & -0.5633 & 1.0000 & & \\
\hline TEMPERATE & 0.4665 & -0.5375 & -0.2672 & 1.0000 & \\
\hline HEIGHTS & -0.1047 & -0.2361 & -0.1173 & -0.1120 & 1.0000 \\
\hline
\end{tabular}

Note: The variable "cold" has been excluded, since there is no observation of social development for any cold country.

We can observe some correlation between the social indicator and the climatic variables; and, what is more important, the correlations corresponding to different climates move in opposite directions. The tropical, dry, and high heights climates give rise to low levels of social development. In particular, desert areas generate the poorest levels of the indicator.

On the other hand, there is a positive correlation between the Adelman and Morris index and the temperate climates. Hence, the temperate climate is positively related to the social capability of a society.

The following series of regressions test the relationship between social capital and climate, and are based on the underlying specification: social development must be, at least partially, explained by climate.

$S_{\text {SOCDEV }}=\beta_{1}$ TROP $_{i}+\beta_{2}$ DRY $_{i}+\beta_{3}$ TEMP $_{i}+\beta_{4}$ COLD $_{i}+\beta_{5}$ HEIGHTS $_{i}+\vec{\beta}$ CONTROLS $_{i}+u_{i}$ 
The first of these regressions runs social development on all the climatic dummies (Table 2, Equation 1). The coefficients corresponding to the climatic dummies should not be interpreted as elasticities, since this is not a comprehensive multivariate regression (which we will see below), but as the evidence of existing differences in the effects of different climates on social capital. From this regression we can see that temperate climate makes a difference as far as the social development index is concerned, obtaining the only significant coefficient with a clearly positive direct relationship to social capital ${ }^{1}$. Temperate climate is revealed as being the most favourable to enable social capability, as opposed to tropical, dry climates or climate of high heights. While temperate climate influences positively, all other types of climate influence slightly negatively on the social capital index, although they do not appear to be statistically significant and might not be very different between them.

As a robustness check, one further consideration would be learning to what extent we can think of the climate coefficients as being different between them. In order to test this, we need a specification with the complete spectrum of climates (Table 2, Equation 1), and then perform the test for all the coefficients being equal at the same time (Table 3, joint Wald test). The result of the Wald test is a probability very close to zero. Therefore, we reassure the conclusions obtained in the last paragraph; we can reject the null hypothesis of social development being indifferent to climate typology.

If we compare the coefficients pairwise, we can test for specific differences between them. This test is particularly interesting in order to contrast the tropical, dry, and high heights coefficients, given that they still look very similar to each other. This is done in Table 3. The resulting probabilities suggest that we cannot make a clear difference between these three types of climate when trying to explain social capital, especially in the case of the dry and high heights, whose probability of being equal rises to 0.88 . Dry climate and the climate of heights seem be a hostile atmosphere for social capital proliferation, despite being radically different in temperature and rainfall between them.

Adding other potential variables that may cause social development differences across countries apart from climate, we may find that the educational level, the health environment and the initial level of wealth may have an effect. A country with generally better educated people might be more favourable to build social networks, have more horizontal associations and work for the community. The same would happen with a healthier and wealthier population. The specification has been broadened in order to include these va-

${ }^{1}$ I take the standard significance levels of $95 \%$ confidence intervals in order to refer to the significance or non-significance of the coefficients in the text. Specific significance levels are detailed in the tables. 
riables (Table 2, Equation 2), using the pupil-teacher ratio at secondary school, and the ratio of real government current educational expenditure per pupil at secondary school to real per capita GDP in percentage as educational indicators, life expectancy as a proxy for health, and, finally, the logarithm of the real per capita GDP in 1960, (the time for which the Social Development Index is available).

The results are satisfactory, since we capture 89 percent of the variation in the social capital proxy, the social development index. The $\mathrm{p}$-values for all climates are practically zero, so the climatic dummies are robust to the inclusion of the extra explanatory variables that can affect social capital, and remain strongly significant. While wealth and, especially, education do not overcome the significance test, the high significance of the life expectancy's positive coefficient brings us to investigate the possible links between social capital and the health indicator further. Notice the important fact that just by adding the life expectancy variable to the regression, in addition to the climates, the adjusted Rsquared rises from 20 percent in Equation 1 to between 74 and 87 percent in Equations 2 and 3, depending on which control variables are included in the regression.

The next question is to which extent life expectancy is related to climate. In order to answer this question the life expectancy variable has been regressed on the climatic variables (Table 2, Equation 4), followed by a Wald test for the joint significance of the coefficients (Table 4). This regression reveals that all coefficients are significant and different among them. This suggests that climate exerts at least a twofold influence on social capital: first, climate appears as a statistically significant factor affecting social capital, and; second, climate is also affecting the health conditions.

Even though this paper is not trying to capture growth in a direct mode, but in an indirect manner through the effect of social capital, I below include some regressions run directly on wealth, using as explanatory variables the social capital index, the climatic fictitious variables, and the other variables previously included in the specification for economic growth by Barro and Sala-i-Martin (1995), such as life expectancy, the initial level of education, and the average rate of growth of investment. I use the CGDP relative to U.S $=100$ (current international prices) as a proxy for wealth. Including these regressions in the analysis shows up the final effect on growth, providing a broader view.

The first of the regressions includes the social development index in the wealth equation (Table 2, Equation 5); the second includes the climatic dummies instead (Table 2, Equation 6). Looking at the table we can see that all the coefficients for the mentioned variables are significant and have the expected sign - positive for the social development index, and negative for all the climates with respect to the temperate one. When both social capital and the climatic dummies are introduced simultaneously in the regression (Table 2, Equation 7), all their coefficients remain significant. This means that both factors are relevant to explain relative GDP, 
and one does not completely rule the other out. So, actually, climate is important not only through social capital but beyond social capital. The adjusted R-squared is higher when regressing on climate instead of social capital. This ratifies the previously introduced hypothesis of climate affecting growth in several ways, in addition to affecting social capital directly.

With respect to the other variables of control, if we try to include both social development and the climate zones in the same regression (Table 2, Equation 7), some of their coefficients are pushed out of the significance level, and the adjusted R-squared diminishes instead of increasing. This means that if we want to include both parameters at the same time, one subtracts significance from the other, and are thus related to one another.

TABLE 2.-Multivariate Regressions

\begin{tabular}{|c|c|c|c|c|c|c|c|}
\hline $\begin{array}{l}\text { Dep var } \\
\text { Sample } \\
\text { Incl obs }\end{array}$ & $\begin{array}{c}(1) \\
\text { SOCDEV } \\
125 \\
64\end{array}$ & $\begin{array}{c}(2) \\
\text { SOCDEV } \\
124 \\
35\end{array}$ & $\begin{array}{c}(3) \\
\text { SOCDEV } \\
125 \\
63\end{array}$ & $\begin{array}{c}(4) \\
\text { LIFE EXP } \\
125 \\
120\end{array}$ & $\begin{array}{c}(5) \\
\text { REL GDP } \\
121 \\
39\end{array}$ & $\begin{array}{c}(6) \\
\text { REL GDP } \\
121 \\
45\end{array}$ & $\begin{array}{c}(7) \\
\text { REL GDP } \\
121 \\
39\end{array}$ \\
\hline Soc Dev & - & - & - & - & $\begin{array}{c}11.100 * * * \\
(3.5510)\end{array}$ & - & $\begin{array}{c}6.9163^{*} \\
(3.5216)\end{array}$ \\
\hline Tropical & $\begin{array}{l}-0.0318 \\
(0.1552)\end{array}$ & $\begin{array}{c}-4.6470 * * * \\
(0.5672)\end{array}$ & $\begin{array}{c}-4.0883 * * * \\
(0.3452)\end{array}$ & $\begin{array}{c}59.323 * * * \\
(1.5703)\end{array}$ & - & $\begin{array}{c}-28.676 * * * * \\
(5.2373)\end{array}$ & $\begin{array}{c}-13.898^{*} \\
(7.3321)\end{array}$ \\
\hline Dry & $\begin{array}{c}-0.2643 \\
(0.2279) \\
\end{array}$ & $\begin{array}{c}-4.7570 * * * \\
(0.6190)\end{array}$ & $\begin{array}{c}-3.9833 * * * \\
(0.4351)\end{array}$ & $\begin{array}{c}55.612 * * * \\
(2.7664)\end{array}$ & - & $\begin{array}{c}-29.203 * * * \\
(8.2271)\end{array}$ & $\begin{array}{c}-17.021 * * \\
(7.6513)\end{array}$ \\
\hline Temperate & $\begin{array}{c}1.0100 * * * \\
(0.2333)\end{array}$ & $\begin{array}{c}-4.2427^{* * * *} \\
(0.6283) \\
\end{array}$ & $\begin{array}{c}-3.6284 * * * \\
(0.4268) \\
\end{array}$ & $\begin{array}{c}72.596 * * * \\
(1.7513) \\
\end{array}$ & - & $\begin{array}{l}\text { (Climate of } \\
\text { reference) }\end{array}$ & $\begin{array}{l}\text { (climate of } \\
\text { reference) }\end{array}$ \\
\hline Cold & No obs. & No obs. & No obs. & $\begin{array}{c}75.983 * * * \\
(2.3045) \\
\end{array}$ & - & - & No obs. \\
\hline Heights & $\begin{array}{c}-0.3433 \\
(0.4966) \\
\end{array}$ & $\begin{array}{c}-4.4363 * * * \\
(0.5971) \\
\end{array}$ & $\begin{array}{c}-4.4364 * * * \\
(0.4807) \\
\end{array}$ & $\begin{array}{c}62.117 * * * \\
(2.3725) \\
\end{array}$ & - & $\begin{array}{c}-36.528 * * * \\
(5.4623)\end{array}$ & $\begin{array}{c}-17.291 * * \\
(6.4731)\end{array}$ \\
\hline Life Exp & - & $\begin{array}{c}0.0590 * * * \\
(0.0061)\end{array}$ & $\begin{array}{c}0.0659 * * * \\
(0.0054)\end{array}$ & - & $\begin{array}{l}0.4028^{*} \\
(0.2240)\end{array}$ & $\begin{array}{c}1.2985 * * * \\
(0.1817)\end{array}$ & $\begin{array}{c}0.4461 \\
(0.2769)\end{array}$ \\
\hline Pulpils & - & $\begin{array}{c}0.0003 \\
(0.0007) \\
\end{array}$ & - & - & - & - & - \\
\hline Teach Sec & - & $\begin{array}{c}0.0023 \\
(0.0088)\end{array}$ & - & - & $\begin{array}{l}0.9508 * \\
(0.5503)\end{array}$ & $\begin{array}{c}0.8771 * * \\
(0.3839)\end{array}$ & $\begin{array}{c}0.8641 \\
(0.5172)\end{array}$ \\
\hline Avg Inv & - & - & - & - & $\begin{array}{c}-124.290 * \\
(65.756)\end{array}$ & $\begin{array}{c}-174.699^{* *} \\
(68.392)\end{array}$ & $\begin{array}{c}-145.103 * \\
(74.343)\end{array}$ \\
\hline LGdp & - & $\begin{array}{c}0.1759 \\
(0.1099) \\
\end{array}$ & - & - & - & - & - \\
\hline $\begin{array}{l}\text { Method } \\
\text { Adj R-Squ }\end{array}$ & $\begin{array}{c}\text { OLS } \\
0.1908\end{array}$ & $\begin{array}{c}\text { OLS } \\
0.8655\end{array}$ & $\begin{array}{c}\text { OLS } \\
0.7385\end{array}$ & $\begin{array}{c}\text { OLS } \\
0.2627\end{array}$ & $\begin{array}{c}\text { OLS } \\
0.5403\end{array}$ & $\begin{array}{c}\text { OLS } \\
0.7241\end{array}$ & $\begin{array}{c}\text { OLS } \\
0.6036\end{array}$ \\
\hline
\end{tabular}

Notes: White Heteroskedasticity-Consistent Standard Errors \& Covariance. Standard errors are in parenthesis. Regression (1) and regressions on GDP have also an omitted constant term. ***Statistically significant at the $1 \%$ level. $* *$ Statistically significant at the $5 \%$ level. 
Table 3.-Wald Tests for Statistically Significant Differences on Climates, Equation ${ }^{(1)}$

\begin{tabular}{|c|c|c|c|c|}
\hline $\begin{array}{l}\text { Null } \\
\text { Hypothesis: }\end{array}$ & $\begin{array}{c}\text { Joint Wald } \\
\text { Test: } \\
C(1)=C(4) \\
C(2)=C(4) \\
C(3)=C(4)\end{array}$ & $\begin{array}{l}\text { Wald Test } \\
\text { Tropical } \\
\text { Vs Dry: } \\
\mathrm{C}(1)=\mathrm{C}(2)\end{array}$ & $\begin{array}{l}\text { Wald Test } \\
\text { Dry vs } \\
\text { Heights: } \\
\mathrm{C}(2)=\mathrm{C}(4)\end{array}$ & $\begin{array}{l}\text { Wald Test } \\
\text { Tropical } \\
\text { Vs Heights: } \\
C(1)=C(4)\end{array}$ \\
\hline $\begin{array}{l}\text { F-statistic } \\
\text { Prob } \\
\text { Chi-square } \\
\text { Prob }\end{array}$ & $\begin{array}{c}6.406746 \\
0.0007 \\
19.22024 \\
0.0002\end{array}$ & $\begin{array}{l}0.7113 \\
0.4024 \\
0.7113 \\
0.3990\end{array}$ & $\begin{array}{l}0.0209 \\
0.8855 \\
0.0209 \\
0.8850\end{array}$ & $\begin{array}{l}0.3586 \\
0.5515 \\
0.3586 \\
0.5493\end{array}$ \\
\hline Result: & $\begin{array}{l}\text { We reject the } \\
\text { hypothesis of no } \\
\text { climate effects }\end{array}$ & $\begin{array}{l}\text { We cannot } \\
\text { reject the null } \\
\text { hypothesis of } \\
\text { tropical and } \\
\text { dry coefficients } \\
\text { being equal }\end{array}$ & $\begin{array}{l}\text { High probability } \\
\text { of dry and high } \\
\text { coefficients } \\
\text { being the same }\end{array}$ & $\begin{array}{l}\text { We cannot reject } \\
\text { the hypothesis of } \\
\text { the tropical and } \\
\text { high coefficients } \\
\text { being equal }\end{array}$ \\
\hline
\end{tabular}

Notes: c(1) corresponds to TROPICAL, c(2) to DRY, c(3) to TEMPERATE, and c(4) to HEIGHTS.

TABLE 4.-Wald Tests for Statistically Significant Differences on Climates, Equation (4):

\begin{tabular}{|l|c|}
\hline & $\mathrm{C}(1)=\mathrm{C}(2)$ \\
& $\mathrm{C}(1)=\mathrm{C}(3)$ \\
& $\mathrm{C}(1)=\mathrm{C}(4)$ \\
$\mathrm{C}(1)=\mathrm{C}(5)$ \\
\hline F-statistic & 16.84472 \\
Prob & 0.0000 \\
Chi-square & 67.37888 \\
Prob & 0.0000 \\
\hline Result: & We reject the hypothesis of no \\
& climate effects \\
\hline
\end{tabular}

Notes: Standard errors in parenthesis. c(1) corresponds to TROP, c(2) to DRY, c(3) to TEM, and c(4) to HIGH. ***Statistically significant at the $1 \%$ level.

\section{Conclusions}

The arising conclusion, given the results, is that several factors are interrelated. On the one hand, we can observe a relation between our proxy for the social capital and the climate. The causality must go in the expected direction (climate has an influence on social capital, and not the other way around), since the climate is purely exogenous, and given by nature. 
On the other hand, we have seen that climate affects social capital both in a direct fashion and through the suggested proxy for health - the life expectancy indicator. I encourage a deeper analysis of the links between social capital and health conditions for further research. The findings regarding social capital do not exclude climate having further effects on growth through other channels. In fact, we can, based on our empirical results, claim that climate exerts some influence on growth in addition to directly on social capital. These extra effects may be the ones suggested in the literature and go from agricultural productivity to human efficiency.

As far as social capital is concerned, what makes the difference is not that much the distinction tropical versus non-tropical countries - as suggested by the literature regarding climate and economic growth - but the distinction temperate versus extreme climates. Some typologies bear a strong resemblance in the results; especially the dry and high heights climates, whose probability of having equal coefficients for social capital amounts is high. Thus, both share similar characteristics that influence the structure of socialisation in the same way.

The results can help us to understand a bit more about why some societies perform better than others, and why the same political measures applied to different regions yield different outcomes. However, it is a theoretically devastating finding, because it necessarily implies that there is nothing we can do at its respect. There is nothing we can do to change the climate. Even after the modernisation occurs -though maybe later than desired- the natural tendencies and attitudes associated to climate will persist.

Nevertheless, as a country is developing economically, it becomes stronger to fight climatic difficulties. Mankind may attempt to artificially mutate natural tendencies in order to improve social efficiency. Investments in research could be done in order to find the means to minimise the negative consequences of climate and even to transform some aspects of the climatic manifestations into a positive comparative advantage. It is possible that the same characteristics that today curb the economic development of non-favoured countries give these areas a comparative advantage over the temperate zones in a particular sector of the economy. For example, new products could be developed based on exploring the variety of tropical life. It is the responsibility of the economic and maybe political agents to explore these possibilities.

Finally, this study is a primary attempt at achieving first-instance empirical evidence, but many possible variations capturing different geographic features could be attempted. Further research incorporating more geographic variables and testing for alternatives is strongly encouraged. 


\section{BIBLIOGRAPHY}

Abramovitz, M. (1986) 'Catching Up, Forgoing Ahead, and Falling Behind', Journal of Economic History, XLVI: 385-406.

Acemoglu, D., S. Johnson, and J. A. Robinson (2001) 'The Colonial Origins of Comparative Development: an Empirical Investigation', American Economic Review, 91 (5)

Adelman, I., and C. T. Morris (1965) 'A Factor Analysis of the Interrelationship Between Social and Political Variables and Per Capita Gross National Product', The Quarterly Journal of Economics, Vol. 79, No. 4: 555-578.

- (1967) 'Society, Politics, and Growth', Quarterly Journal of Economics, Vol. 109, Issue 2: 465-490.

Adger, W. NeIl (2003) "Social Capital, Collective Action, and Adaptation to Climate Change", Economic Geography 79 (4): 387-404.

Bleaney, M. and A. Nishiyama (2002) 'Explaining Growth: A Contest Between Models', Journal of Economic Growth, Vol. 7: 43-56.

BARRO, R. J. (1991) 'Economic Growth in a Cross Section of Countries', Quarterly Journal of Economics, 106 (2): 407-443.

- (1997) 'Determinants of Economic Growth: A Cross-Country Empirical Study', MIT Press (Cambridge, MA).

CHou, Y. K. (2006) “Three Simple Models of Social Capital and Economic Growth", Journal of Socio-Economics 35 (5): 889-912.

Coleman, J. S. (1988) "Social Capital in the Creation of Human Capital", The American Journal of Sociology, 94(Supplement: Organisations and Institutions: Sociological and Economic Approaches to the Analysis of Social Structure):S95-S120.

Dinda, S. (2008) "Social Capital in the Creation of Human Capital and Economic Growth: A Productive Consumption Approach" Journal of Socio-Economics, 37(5): 2020-2033.

EAsterly, W., and Ross L. (1997) 'Africa's Growth Tragedy: Policies and Ethnic Divisions', Quarterly Journal of Economics, Vol. 112, Issue 4: 1203-50.

- (2003) 'Tropics, Germs and Crops: How Endowments Influence Economic Development', Journal of Monetary Economics, 50 (1): 3-39.

Engerman, S. L., and K. L. SoKoloff (1997) 'Factor Endowments, Institutions, and Differential Paths of Growth Among New World Economies', in S. Haber (ed.), How Latin America Fell Behind: Essays on the Economic Histories of Brazil and Mexico, 1800-1914, (Stanford University Press), Chapter 10: 260-291.

- (2002) 'Factor Endowments, Inequality and Paths of Development Among New World Economies', Economía (The Brookings Institution), 3 (1):41-109. 
FukUYama, F. (1995) "Social Capital and the Global Economy", Foreign Affairs, 74(5): 89103.

Gallup, J. L., and JefFrey D. S. (1999) 'Geography and Economic Development', CAER II Discussion Paper $\mathrm{N}^{\circ} 39$.

- (1999) 'Malaria, Climate, and Poverty', CAER II Discussion Paper 48.

- with A. D. Mellinger (1999) 'Geography and Economic Development', International Regional Science Review 22 (2): 179-232.

Guiso, L., P. SAPIEnZA, and L. Zingales (2004) 'The Role of Social Capital in Financial Development', The American Economic Review, 94 (3): 526-556.

Hall, R. E., and C. I. Jones (1999) 'Why Do Some Countries Produce so Much More Output per Worker than Others?', Quarterly Journal of Economics, CXIV: 83-116.

Heston, A., and R. Summers (1991) 'The Penn World Table: An Expanded Set of International Comparisons, 1950-1988', Quarterly Journal of Economics: 327-368.

KnaCK, S. and P. Keefer (1997) 'Does Social Capital Have an Economic Payoff? A CrossCountry Investigation', The Quarterly Journal of Economics, CXII: 1251-1288.

La Porta, R., F. Lopez-DE-Silanes, A. Shleifer, and R. W. Vishny (1997) 'Trust in Large Organisations', American Economic Review Papers and Proceedings, 87: 333-338.

LEE, J.-W., and R. J. BARRo (2001) 'Schooling Quality in a Cross-Section of Countries', Economica 68 (262): 465-488.

National Bureau of Economic Research. www.nber.org/data_index.html.

Putnam, R. D. (1993) Making Democracy Work (Princeton University Press).

- (2000) Bowling Alone. The Collapse and Revival of American Community, Simon \& Schuster, (New York).

Redding, S. and A. J. Venables (2004) 'Economic Geography and International Inequality' Journal of International Economics, 62 (1):53-82.

Rodrik, D., A. Subramanian, and F. Trebi (2004) 'Institutions Rule: The Primacy of Institutions over Geography and Integration in Economic Development', Journal of Economic Growth 9 (2): 131-165.

SACHS, J. D. (2003) 'Institutions Don't Rule: Direct Effects of Geography on Per Capita Income', NBER Working Paper Series 9490.

- and A. WARNER (1997) 'Sources of Slow Growth in African Economies', Journal of African Economies, 6: 335-376.

Schimidt-Hebbel, K. (1996) 'Fiscal Adjustment and Growth: In and Out of Africa', Journal of African Economies, 5 (3): 7-59.

Sen, A. K. (1981), Poverty and Famines: An Essay on Entitlement and Deprivation, Oxford (UK): Clarendon. 
Temple, J. (1998) 'Initial Conditions, Social Capital, and Growth in Africa', Journal of African Economies, 7(3): 309-347.

- and P. A. JoHnson (1998) 'Social Capability and Economic Growth', The Quarterly Journal of Economics, Vol. 113, Issue 3: 965-990.

THE WORLD FACTBOOK, www.economics.about.com/gi/dynamic/offsite.htm?site=http://www. odci.gov/cia/publications/factbook/index.html.

Woolcock, M. (1998) 'Social capital and economic development: toward a theoretical synthesis and policy framework', Theory and Society, 27: 151-208.

ZAK, P. J. and S. KNACK (2001) 'Trust and Growth', The Economic Journal, vol. 111, no. 470: 295-321. 